\title{
Assessing air pollution tolerance of plant species in vegetation traffic barriers in Kathmandu Valley, Nepal
}

\author{
Sunita Shrestha', Badri Baral ${ }^{2,3}$, Narayan Babu Dhital ${ }^{4,5,6}$ and Hsi-Hsien Yang $^{5^{*}}$ (D)
}

\begin{abstract}
Vegetation traffic barriers along roads can be an effective structure to improve roadside air quality and to reduce human exposure to traffic air pollutants. However, the selection of the plant species should be considered as an important design parameter for vegetation traffic barriers because different plant species demonstrate different levels of tolerance to air pollutants. This study compares the air pollution tolerance of different plant species found in the vegetation traffic barriers in the Kathmandu valley. Four biochemical parameters (relative water content, leaf extract pH, total chlorophyll and ascorbic acid) and the dust-capturing potential of plants were analyzed. Out of the nine selected species, Cinnamomum camphora showed the highest tolerance to air pollution based on the air pollution tolerance index. Similarly, Schefflera pueckleri, Psidium guajava and Ficus benjamina were found to be the sensitive species, while Ficus sp., Nerium oleander, Thuja sp., Dypsis lutescens and Albizia julibrissin were found to have a moderate level of tolerance to air pollution. $N$. oleander had the highest dust-capturing potential.

Considering both air pollution tolerance index and dust-capturing potential, C. camphora, N. oleander and A. julibrissin were found to be the most suitable species for the roadside plantation. The findings of this study might have important implications for plant species selection for vegetation traffic barriers.
\end{abstract}

Keywords: Air pollution tolerance index, Biochemical parameters, Dust capturing potential, Vegetation traffic barrier

\section{Introduction}

Urban air pollution is one of the major atmospheric pollution issues that is getting worse with the growing urban population, increasing traffic density and industrialization [1]. Air pollution is one of the leading risk factors for disease burden [2,3] and causes effects ranging from mild health problems to death [2]. Around $90 \%$ of the global population lives in places where air quality does not comply with WHO air quality guidelines [4]. Transport is one of the major sectors of urban air pollution worldwide [5]. Roadside air quality is aggravated due to high traffic density, old vehicles, poor fuel quality, poor road and inadequate inspection and maintenance programs [6]. The

\footnotetext{
* Correspondence: hhyang@cyut.edu.tw

${ }^{5}$ Department of Environmental Engineering and Management, Chaoyang

University of Technology, Taichung 413310, Taiwan

Full list of author information is available at the end of the article
}

environmental performance index ranked Nepal's air quality at the 178th position out of 180 in 2020 [7]. Kathmandu, the capital city of Nepal with dense settlement areas and below global average open green space per capita [8], has been reported to be one of the highly polluted cities in Asia.

It is difficult to completely control the emission of air pollutants at the source. Thus, reducing human exposure is one of the important aspects of air quality management. Vegetation might help reduce human exposure to traffic emissions through dry deposition of pollutants on vegetation surfaces [9]. Vegetation traffic barrier is one of the several promising passive control systems for air pollution [10]. It offers a porous medium that provides a barrier between vehicular emissions and adjacent population by influencing local turbulence and modifying natural dispersion [9]. It is a cost-effective and

(c) The Author(s). 2021 Open Access This article is licensed under a Creative Commons Attribution 4.0 International License, which permits use, sharing, adaptation, distribution and reproduction in any medium or format, as long as you give appropriate credit to the original author(s) and the source, provide a link to the Creative Commons licence, and indicate if changes were made. The images or other third party material in this article are included in the article's Creative Commons licence, unless indicated otherwise in a credit line to the material. If material is not included in the article's Creative Commons licence and your intended use is not permitted by statutory regulation or exceeds the permitted use, you will need to obtain permission directly from the copyright holder. To view a copy of this licence, visit http://creativecommons.org/licenses/by/4.0/. 
environmentally friendly option against other technological and mechanized methods to mitigate air pollution. It provides several other ecosystem co-benefits like temperature and storm water regulation, noise reduction, etc. It has been found that plants can filter certain pollutants through absorption, adsorption and metabolism [11]. Thus, plants act as an important sink of air pollutants [12]. Deposition rates of air pollutants on vegetation have been found higher than those on the built-up structures [13]. Vegetation provides sites for gravity or wind-blown settlement of air pollutants [14]. Furrowed areas of leaf surfaces can provide effective sites for particulate matter deposition [15]. Moreover, urban vegetation may also help reduce the urban heat island effect [16]. So, vegetation traffic barriers with a proper design could provide the benefit of reducing air pollution exposure. Planting vegetation for air-quality improvement has been well accepted in many developed countries [11]. However, not all plant species offer equal benefits in minimizing urban air pollution. Some plant species may even act as the source of pollutants such as biogenic volatile organic carbon. Studies have shown that the selection of plant species for roadside plantation might have a substantial effect on volatile organic carbon emissions [17]. Therefore, plant species selection should be considered carefully while designing urban green belts and vegetation traffic barriers [18].

Plant's ability to tolerate air pollutants depends on its biochemical, physiological and morphological characteristics [11]. Air pollution tolerance index (APTI) describes the inherent quality of plants to tolerate air pollution. It is one of the important parameters that could be considered for the selection of traffic barrier plant species. It is an important tool to categorize plants based on their tolerances or sensitivity levels to air pollutants. APTI of plants has been described with four biochemical parameters: total chlorophyll, relative water content (RWC), ascorbic acid and leaf extract $\mathrm{pH}$. Pollution-induced alterations in a single parameter may not depict a clear picture of the situation. So, four biochemical parameters are considered to obtain an empirical value representing the APTI of plants [19]. The gradual disappearance of chlorophyll and yellowing of leaves is one of the common effects of air pollution that reduces photosynthesis. Ascorbic acid is an important electron donor in photosynthesis [20]. Photosynthetic activity is strongly dependent on $\mathrm{pH}$ [21]. These biochemical parameters are dependent on each other and most responsive to air pollution. Based on APTI values, low APTI plant species can be used in low pollution areas as bio-indicators, while high APTI plant species can be used in highly polluted areas to mitigate air pollution [22, 23].
There are several studies conducted on the suitability of plant species to be used in urban green belts [22-24]. Most of these studies have been conducted in India and China. However, the findings of these studies cannot be simply generalized over different regions because of the differences in biogeographic and climatic conditions in different areas. Thus, the present study was conducted in the Kathmandu valley to evaluate air pollution tolerance and dust-capturing potential of plant species used in the vegetation traffic barrier along the KathmanduBhaktapur road section.

\section{Materials and methods \\ Study area}

Samples for the present study were collected from the Kathmandu-Bhaktapur road section from Koteshwor bus stand $\left(27^{\circ} 40^{\prime} 39.93^{\prime \prime} \mathrm{N}\right.$ and $\left.85^{\circ} 20^{\prime} 58.46^{\prime \prime} \mathrm{E}\right)$ to Sallaghari $\left(27^{\circ} 40^{\prime} 18.26^{\prime \prime} \mathrm{N}\right.$ and $\left.85^{\circ} 24^{\prime} 29.99^{\prime \prime} \mathrm{E}\right)$ at an elevation of $1312-1310 \mathrm{~m}$ asl (Fig. 1). The road section is a six-lane highway that connects Kathmandu district with Bhaktapur district in the Kathmandu valley [25]. The study area features a warm and temperate climate with an average annual temperature of $19.5^{\circ} \mathrm{C}$ and about $1089 \mathrm{~mm}$ annual precipitation in 2017 [26]. The main sources of air pollutants in the study area are road traffic and industries.

\section{Sampling and analysis}

The study was undertaken during the month of January-March, 2018. Six stretches, each of $1 \mathrm{~km}$ length, were selected along the Koteshwor-Sallaghari road section for sample collection. The sampled road section featured approximately $3 \mathrm{~m}$ wide vegetation traffic barriers in the middle of the road to separate opposing traffic lanes. Different plant species have been grown in the traffic barrier. The traffic barrier vegetation had nearly a uniform height. Nine most abundant plant species found along the traffic barrier were selected for the analysis. The selected plant species were Albizia julibrissin, Cinnamomum camphora, Dypsis lutescens, Ficus benjamina, Ficus sp., Nerium oleander, Psidium guajava, Schefflera pueckleri and Thuja sp.

For each of the selected plant species, fresh mature leaves were collected from $2 \mathrm{~m}$ height during the morning hours (08:00-11:30). Sampling was done in triplicate. The sample leaves were kept in polythene bags and brought to the laboratory in an icebox (Marina cooler, $18 \mathrm{~S})$ for further analysis. The samples of each plant species obtained from the same road stretch were mixed to make a composite sample for each road stretch. Thus, there were six composite samples, each corresponding to one of the six road sections for each species. Three replicate analyses were done for each composite samples. Moreover, to estimate the dust-capturing potential of 


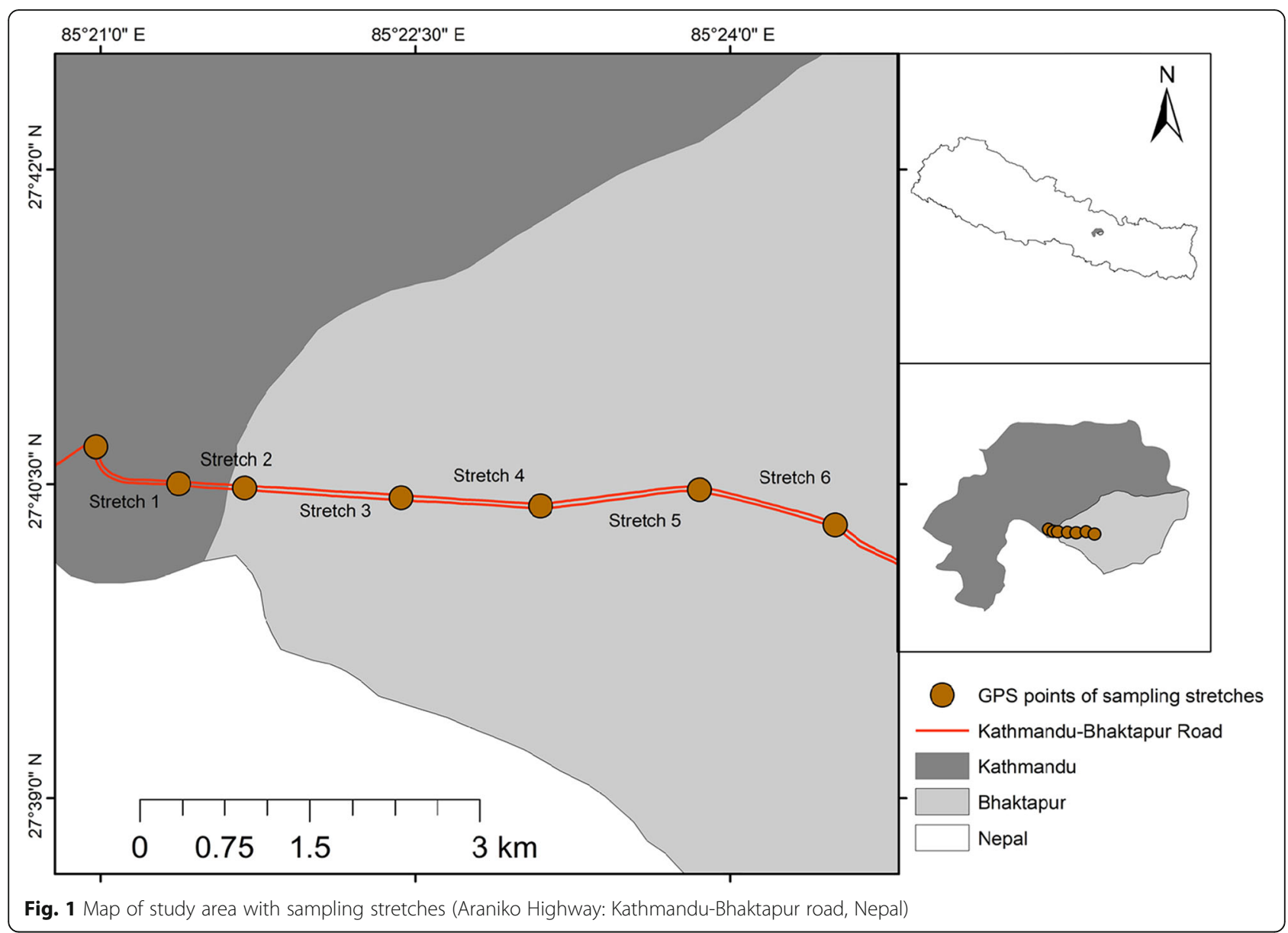

the leaves, three matured leaves of the selected plant species were washed in the early morning (08:00-11:00) from each of the six road stretches. The upper and lower surfaces of leaves were cleaned using a fine brush and distilled water. The selected leaves were marked and left for $24 \mathrm{~h}$. The marked leaves were cut from the petiole on the next day. The leaves were put in pre-weighted zip lock bags and brought to the laboratory. After the leaves were air-dried, a five-digit electronic balance (Kern, ABT-BA-def-0911) was used for the measurement of leaf weights. After that, dust on leaves was cleaned with the help of fine brush and distilled water and blotted dry with blotting paper. The leaves were again air-dried and weighted. The leaf area was measured using ImageJ software [27].

\section{RWC}

Three different weights of the leaves (fresh weight taken immediately after collecting leaves, turgid weight after immersing in water overnight and the dry weight after drying in hot air oven at $70^{\circ} \mathrm{C}$ overnight; Vitco, Universal hot air oven) were used for calculating the RWC of leaves [28]. The RWC was calculated using Eq. (1).

$$
\mathrm{RWC}=\frac{\mathrm{FW}-\mathrm{DW}}{\mathrm{TW}-\mathrm{DW}} \times 100 \%
$$

where, $\mathrm{FW}=$ fresh weight, $\mathrm{DW}=$ dry weight, and $\mathrm{TW}=$ turgid weight.

\section{Total chlorophyll}

A crushed leaf sample $(5 \mathrm{~g})$ was taken, and $10 \mathrm{~mL}$ of $80 \%$ acetone was added to it. Then, the sample was left aside for $15 \mathrm{~min}$ for thorough extraction. The leaf extract so obtained was decanted into centrifuge tubes and was centrifuged (Remi, R-8C) at $2500 \mathrm{rpm}$ for $10 \mathrm{~min}$. Then, the absorbance was taken at $645 \mathrm{~nm}$ and $663 \mathrm{~nm}$ using a spectrophotometer (SSI, UV 2101) after calibrating it against reagent blank. The total chlorophyll content was calculated using Eq. (2) [29, 30]. The details of the methods can be found elsewhere [29].

$$
\begin{aligned}
\mathrm{TCh}= & {[20.2(\mathrm{~A} 645)+8.02(\mathrm{~A} 663)] } \\
& \times\left[\frac{\mathrm{v}}{(1000 \times \mathrm{W})}\right]
\end{aligned}
$$

where, $\mathrm{TCh}=$ total chlorophyll $\left(\mathrm{mg} \mathrm{g}^{-1}\right), \mathrm{A} 645=$ absorb ance at $645 \mathrm{~nm}, \mathrm{~A} 663=$ absorbance at $663 \mathrm{~nm}, \mathrm{~V}=$ total 
volume of the extract $(\mathrm{mL})$, and $\mathrm{W}=$ weight of the sample (g).

\section{Leaf-extract $p H$}

A part of the leaf sample $(5 \mathrm{~g})$ was crushed and homogenized in $50 \mathrm{~mL}$ deionized distilled water. The sample was filtered and the $\mathrm{pH}$ of leaf suspension was measured using a $\mathrm{pH}$ meter (YSI, 1200).

\section{Ascorbic acid}

A part of fresh leaf tissue $(1 \mathrm{~g})$ was crushed and put in a test-tube. Then, $4 \mathrm{~mL}$ oxalic-ethylenediaminetetraacetic acid extracting solution was added to the test-tube followed by $1 \mathrm{~mL}$ orthophosphoric acid, $1 \mathrm{~mL}$ of sulphuric acid (5\%), $2 \mathrm{~mL}$ ammonium molybdate (5\%) and $3 \mathrm{~mL}$ distilled water. The solution was allowed to stand for $15 \mathrm{~min}$ and the absorbance was measured at $760 \mathrm{~nm}$ with a spectrophotometer (SSI, UV 2101). The concentration of ascorbic acid was obtained from the standard curve of ascorbic acid in $\mathrm{mg} \mathrm{mL}^{-1}$ and converted to ascorbic acid content per gram dry weight [31]. Further details of the analytical methods can be found elsewhere [31].

APTI

APTI was calculated using Eq. (3) [19, 23].

$$
\text { APTI }: \frac{[\mathrm{A}(\mathrm{T}+\mathrm{P})+(\mathrm{R})]}{10}
$$

where, $\mathrm{A}=$ Ascorbic acid content $\left(\mathrm{mg} \mathrm{g}^{-1}\right)$ (dry weight), $\mathrm{T}=$ Total chlorophyll content $\left(\mathrm{mg} \mathrm{g}^{-1}\right), \mathrm{P}=$ leaf extract $\mathrm{pH}$, and $\mathrm{R}=\mathrm{RWC}(\%)$.

APTI values were categorized into three groups (Table 1) as suggested by Bharti et al. [22] and Ogunkunle et al. [32].

\section{Dust-capturing potential}

The dust-capturing potential of leaves was calculated using Eq. (4):

$$
\mathrm{W}=\frac{(\mathrm{W} 1-\mathrm{W} 2-\mathrm{W} 3)}{\mathrm{A}}
$$

Table 1 Categories of plant species based on air pollution tolerance index

\begin{tabular}{lll}
\hline S/N & APTI value & Response \\
\hline 1 & $1-11$ & Sensitive \\
2 & $12-16$ & Intermediate \\
3 & $\geq 17$ & Tolerant \\
\hline
\end{tabular}

where $\mathrm{W}=$ dust-capturing potential $\left(\mathrm{g} \mathrm{cm}^{-2}\right), \mathrm{W}_{1}=$ weight of leaf with dust and zip lock bag (g), $\mathrm{W}_{2}=$ weight of leaf after removing dust $(\mathrm{g}), \mathrm{W}_{3}=$ weight of zip lock bag $(\mathrm{g})$, and $\mathrm{A}=$ total area of leaf $\left(\mathrm{cm}^{2}\right)$.

\section{Results and discussion \\ RWC}

RWC of the selected plant species ranged from 26.4 to 91.4\% (Fig. 2). RWC of most of the plant species was found $>40 \%$ in the present study. RWC can be as high as $98 \%$ in fully turgid transpiring leaves, while it can be as low as 30$40 \%$ in severely drying leaves depending on the plant species [33]. Higher RWC has been reported in plants from polluted sites [24, 34]. The maximum RWC was found for S. pueckleri $(91.4 \%)$ followed by Ficus sp. (85.5\%), C. camphora (84.2\%), N. oleander (67.4\%), P. guajava (55.6\%), F. benjamina (54.9\%), D. lutescens (49.2\%), A. julibrissin (30.2\%), and Thuja sp. (26.4\%) (Fig. 2). High RWC helps plant species to survive in long dry seasons [35]. In contrast to the results of the present study, Kanwar et al. [24] report high RWC in Thuja sp. (92.3\%). The observed differences could be because of the differences in the sampling period, site, irradiance, temperature, humidity and soil salinity [36]. A decrease in RWC lowers stomatal conductance and hence $\mathrm{CO}_{2}$ assimilation [37]. Net $\mathrm{CO}_{2}$ exchange, $\mathrm{CO}_{2}$ assimilation and photosynthetic potential become zero at very small RWC (approx 40\%) [37]. Under stressed conditions, such as exposure to air pollution, transpiration rates of plants could increase. A higher RWC gives plants a better tolerance capacity against air pollution [38].

\section{Total chlorophyll}

The total chlorophyll content was found to range from 0.106 to $1.38 \mathrm{mg} \mathrm{g}^{-1}$ (Fig. 3). The maximum total chlorophyll content was found in C. camphora $(1.38 \mathrm{mg}$ $\left.\mathrm{g}^{-1}\right)$ followed by $A$. julibrissin $\left(1.26 \mathrm{mg} \mathrm{g}^{-1}\right)$, D. lutescens $\left(0.417 \mathrm{mg} \mathrm{g}^{-1}\right)$, S. pueckleri $\left(0.364 \mathrm{mg} \mathrm{g}^{-1}\right)$, P. guajava $\left(0.238 \mathrm{mg} \mathrm{g}^{-1}\right)$, F. benjamina $\left(0.199 \mathrm{mg} \mathrm{g}^{-1}\right)$, Thuja sp. $\left(0.192 \mathrm{mg} \mathrm{g}^{-1}\right)$ Ficus sp. (0.140 $\left.\mathrm{mg} \mathrm{g}^{-1}\right)$ and $N$. oleander $\left(0.106 \mathrm{mg} \mathrm{g}^{-1}\right)$. In a study conducted by Li et al. [39], the total chlorophyll content in 823 plant species ranges from 1.2 to $22.6 \mathrm{mg} \mathrm{g}^{-1}$. The total chlorophyll contents in the selected plant species were relatively lower in the present study. This could be an effect of the stress induced by air pollutants. Total chlorophyll is considered as an index of photosynthetic activity, growth and biomass productivity [40, 41]. Degradation of photosynthetic pigments has been widely used as an indicator of air pollution, and a decrease in chlorophyll content shows that plants are more sensitive to air pollution [42]. Therefore, Thuja sp., N. oleander, Ficus sp., F. benjamina were likely to be more sensitive to air pollution than $C$. camphora and A. julibrissin. A decrease in chlorophyll content decreases the productivity of plants 


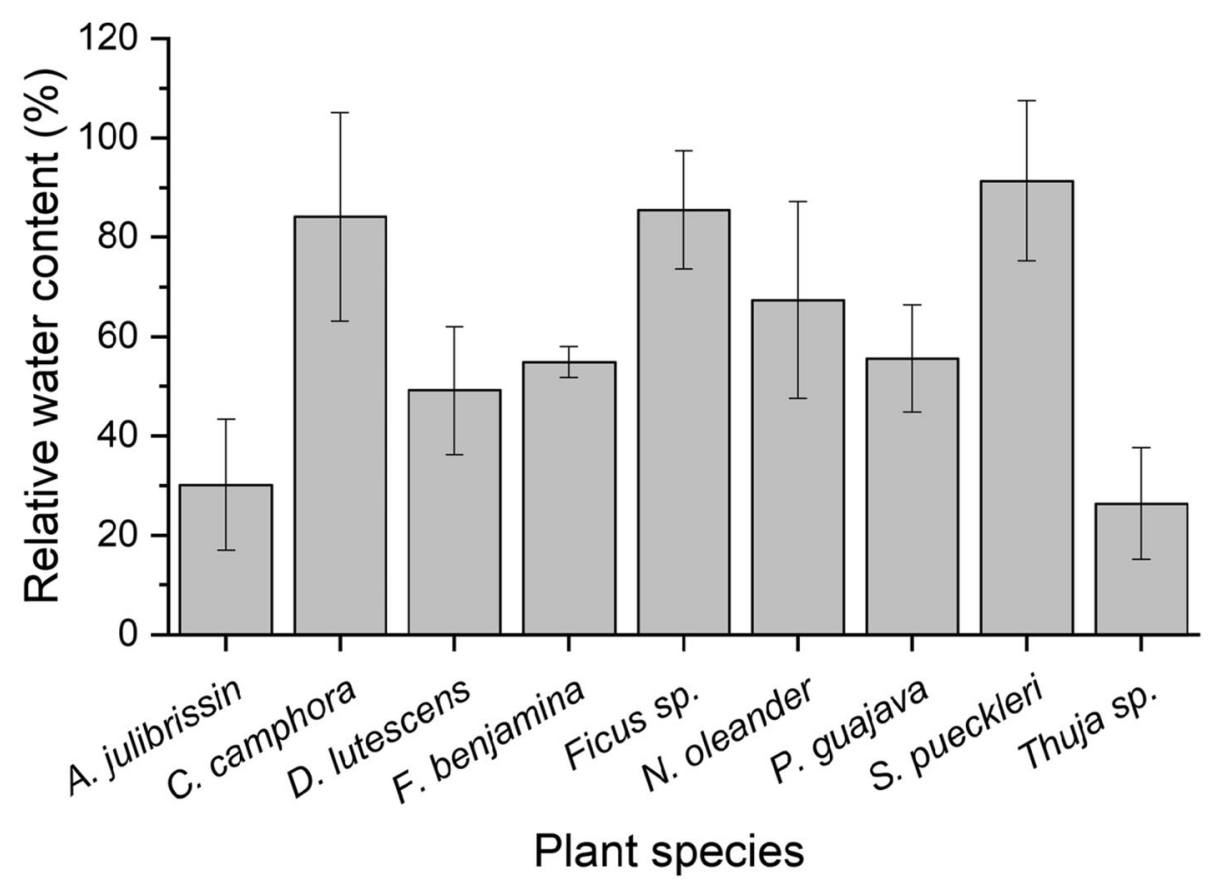

Fig. 2 Average relative water content of the selected plant species; error bars represent the standard deviation $(n=6)$

and hence the resistance of plants to air pollution. Air pollutants like sulphur dioxide, nitrogen dioxide, carbon dioxide and suspended particulate matter may lower the chlorophyll concentration [40] as the pollutants enter into tissues through stomata and cause partial denaturation of chloroplasts.

\section{Leaf extract $\mathrm{pH}$}

The leaf extract $\mathrm{pH}$ of the selected plant species ranged from 5.13 to 8.44 (Fig. 4). The highest $\mathrm{pH}$ was observed for F. benjamina (8.44) followed by C. camphora (7.71), Thuja sp. (7.69), S. pueckleri (7.66), P. guajava (7.58), Ficus sp. (7.29), N. oleander (5.94), D. lutescens (5.48),

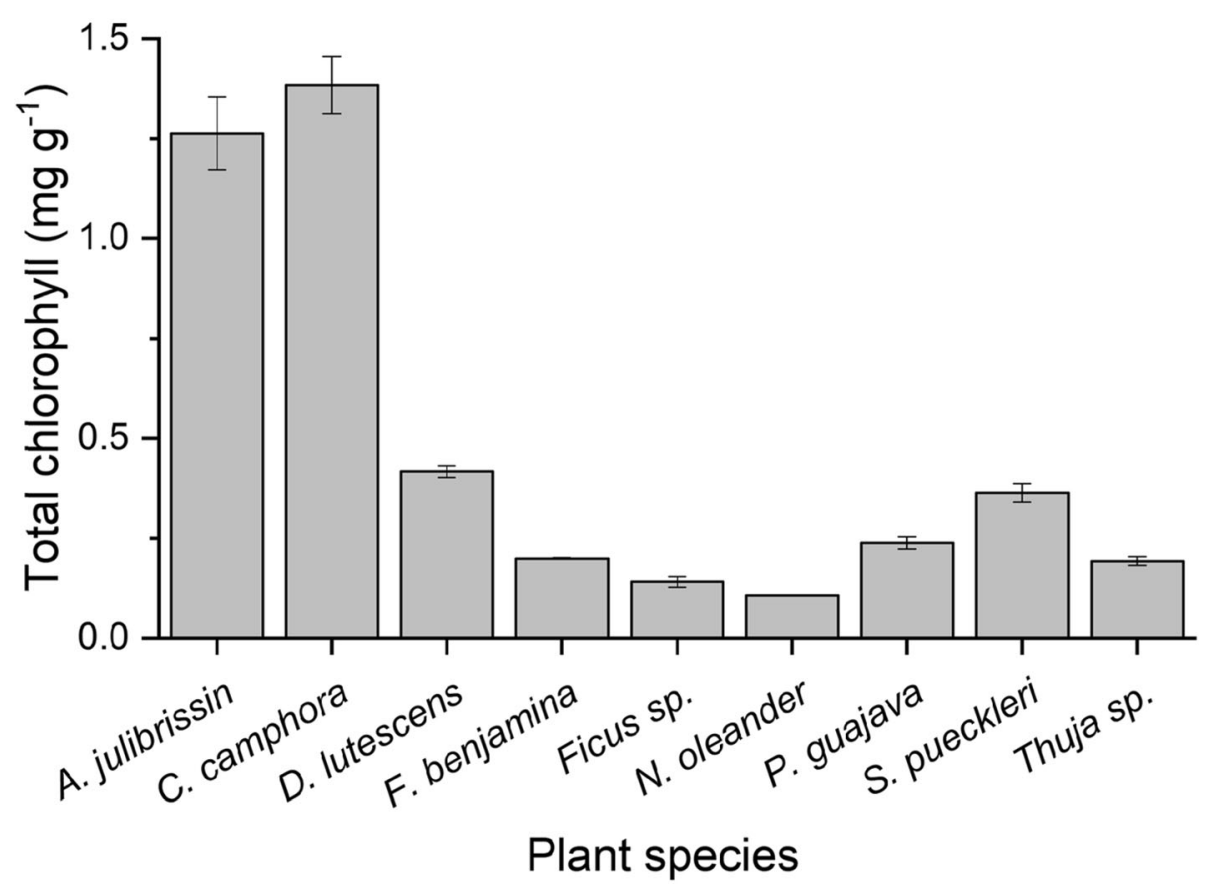

Fig. 3 Average total chlorophyll content of the selected plant species; error bars represent the standard deviation $(n=6)$ 


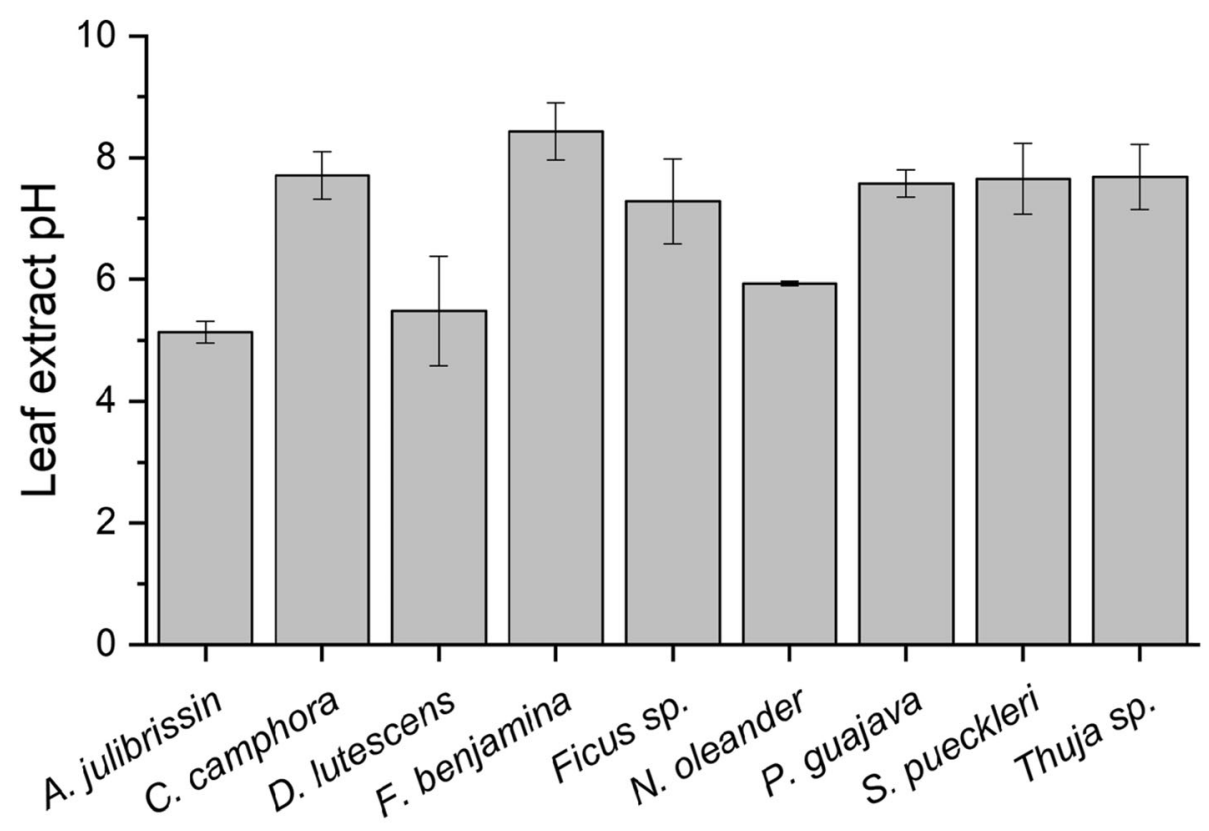

Plant species

Fig. 4 Average leaf extract pH of the selected plant species; error bars represent the standard deviation $(n=6)$

and A. julibrissin (5.13). Plants having leaf extract $\mathrm{pH}$ around 7 and higher are more tolerant of air pollution than those having low pHs [38]. Most of the plant species selected in the present study had $\mathrm{pH}$ values above 7 . A lower leaf extract $\mathrm{pH}$ can be observed in the plants exposed to acidic pollutants such as $\mathrm{SO}_{x}, \mathrm{NO}_{x}, \mathrm{CO}_{2}$ [43]. The activity of ascorbic acid is also $\mathrm{pH}$-dependent which is high at higher $\mathrm{pH}$ and low at lower $\mathrm{pH}$. Therefore, high leaf extract $\mathrm{pH}$ makes plants more tolerant of air pollution [38]. Lower leaf extract $\mathrm{pH}$ may reduce the

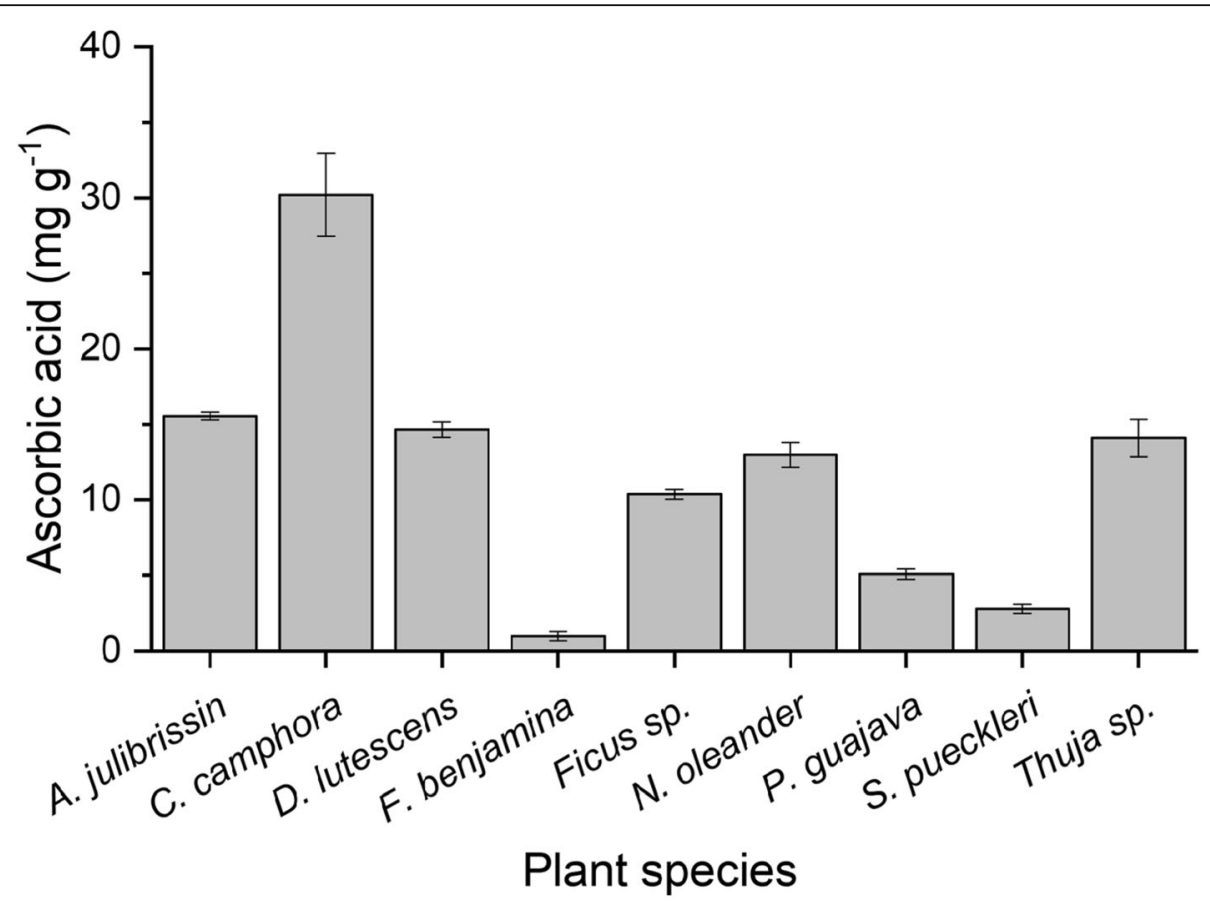

Fig. 5 Average ascorbic acid of the selected plant species; error bars represent the standard deviation $(n=6)$ 
chlorophyll content of the plant species and hence the capacity to tolerate air pollution.

\section{Ascorbic acid}

The ascorbic acid content in the selected plant species ranged from 0.975 to $30.2 \mathrm{mg} \mathrm{g}^{-1}$. The highest ascorbic acid content was observed for C. camphora $(30.2 \mathrm{mg}$ $\mathrm{g}^{-1}$ ) followed by A. julibrissin (15.6 $\left.\mathrm{mg} \mathrm{g}^{-1}\right)$, D. lutescens (14.7 $\left.\mathrm{mg} \mathrm{g}^{-1}\right)$, Thuja sp. $\left(14.1 \mathrm{mg} \mathrm{g}^{-1}\right)$, N. oleander (13.0 $\left.\mathrm{mg} \mathrm{g}^{-1}\right)$, Ficus sp. $\left(10.4 \mathrm{mg} \mathrm{g}^{-1}\right)$, P. guajava $(5.08 \mathrm{mg}$ $\left.\mathrm{g}^{-1}\right)$, S. pueckleri $\left(2.79 \mathrm{mg} \mathrm{g}^{-1}\right)$ and F. benjamina $(0.975$ $\mathrm{mg} \mathrm{g}^{-1}$ ) (Fig. 5). Ascorbic acid is an antioxidant that provides resistance to plants in a stressed condition. With the increase in pollution, ascorbic acid content also increases to combat the stressed condition [22]. It acts as a powerful reductant [44], electron donor, scavenges free oxygen radicals, facilitates the reduction of sulphite to hydrogen sulphide and reduces the toxicity of $\mathrm{SO}_{2}$ [45]. Plants having high ascorbic acid possess resistance to $\mathrm{SO}_{2}$ [45]. So, C. camphora, A. julibrissin, N. oleander might have a better capacity to combat air pollution. Ascorbic acid helps in the defense mechanism and tolerating the ill effects of air pollutants [46].

\section{APTI}

APTI of the selected plant species ranged from 6.33 to 36.0. The highest APTI was exhibited by C. camphora and the lowest by $F$. benjamina. The order of APTI values of the selected plant species was: $C$. camphora $>$ Ficus sp. $>N$. oleander $>$ Thuja sp. $>$ D. lutescens $>A$. julibrissin $>$ S. pueckleri $>$ P. guajava $>F$. benjamina. $C$. camphora was found to be a tolerant species; S. pueckleri, P. guajava, F. benjamina were found to be the sensitive species and Ficus sp., $N$. oleander, Thuja sp., D. lutescens, A. julibrissin were found to have intermediate tolerance to air pollution (Table 2). Unlike the finding of the present study, F. benjamina has been reported as a tolerant species in a study conducted by Pandey et al. [47]. This could be because of the fact that APTI of

Table 2 Average $(n=6)$ air pollution tolerance index of the studied plant species

\begin{tabular}{llll}
\hline S/N & Name of plant species & APTI (Mean \pm SD) & Response \\
\hline 1 & Cinnamomum camphora & $36.0 \pm 5.6$ & Tolerant \\
2 & Ficus sp. & $16.3 \pm 2.3$ & Intermediate \\
3 & Nerium oleander & $14.6 \pm 3.1$ & Intermediate \\
4 & Thuja sp. & $13.7 \pm 1.5$ & Intermediate \\
5 & Dypsis lutescens & $13.6 \pm 1.0$ & Intermediate \\
6 & Albizia julibrissin & $13.0 \pm 1.6$ & Intermediate \\
7 & Schefflera pueckleri & $11.4 \pm 2.1$ & Sensitive \\
8 & Psidium guajava & $9.5 \pm 1.4$ & Sensitive \\
9 & Ficus benjamina & $6.3 \pm 0.7$ & Sensitive \\
\hline
\end{tabular}

plants may vary from place to place due to geographic and climatic variations [30]. It also varies because of differences in air quality, temperature, humidity, etc. [48]. The sensitive plant species identified in the present study could be potentially used as bio-indicators of air quality while the tolerant species could be used in vegetation traffic barriers and urban green belts [22, 23, 34].

\section{Dust-capturing potential}

The median dust-capturing potentials of the selected plants ranged from 0.00026 to $0.0018 \mathrm{~g} \mathrm{~cm}^{-2}$ (Table 3). The maximum dust-capturing potential was found for N. oleander followed by A. julibrissin, S. pueckleri, C. camphora, G. jasminoides, Ficus sp. and F. benjamina. The plant species with the higher dust-capturing potentials help in reducing particulate matter in the roadside atmosphere [49]. They play as a biological air filter. Shrubs with foliar leaves arrest more particulate matter than large trees [50]. Plants have different inherent morphological traits like phyllotaxy, leaf shape, size and texture, presence or absence of hairs, stomatal frequency, surface roughness, stomatal density, and trichome length that determines their dust collecting capacity [51].

The results of the present study suggest that C. camphora, N. oleander and A. julibrissin were tolerant of air pollution considering both APTI and dust-capturing potential. The air pollution tolerance of plant species varies with seasons [52] and with several environmental variables [48]. A limitation of the present study is that it covers a small spatial and temporal scale. However, it provides some important insights and foundation for further research in the geographical area considered in the present study. Future works might be done covering a larger temporal and spatial scale and considering meteorological and air quality parameters.

\section{Conclusions}

This study evaluated the suitability of plant species for vegetation traffic barriers. Among the nine selected plant species, Cinnamomum camphora, Nerium oleander and

Table 3 Median $(n=6)$ dust capturing potential of the studied plant species

\begin{tabular}{llll}
\hline $\mathbf{S} /$ & Plant species & \multicolumn{2}{l}{ Dust capturing potential $\left(\mathbf{g ~ c m}^{\mathbf{- 2}}\right)$} \\
\cline { 3 - 4 } $\mathbf{N}$ & & Median & $\mathbf{I Q R}^{\mathbf{a}}$ \\
\hline 1 & Cinnamomum camphora & 0.00064 & 0.0030 \\
2 & Ficus benjamina & 0.00026 & 0.00028 \\
3 & Ficus sp. & 0.00030 & 0.00014 \\
4 & Nerium oleander & 0.0018 & 0.0013 \\
5 & Schefflera pueckleri & 0.00069 & 0.00051 \\
6 & Albizia julibrissin & 0.00088 & 0.00042 \\
7 & Gardenia jasminoides & 0.00031 & 0.00013 \\
\hline
\end{tabular}

Interquartile range 
Albizia julibrissin were found to be the most suitable species to be used in the vegetation traffic barriers based on air pollution tolerance and dust-capturing potential. The finding of the present study might be useful for designing urban green belts and vegetation traffic barriers in the Kathmandu valley.

\section{Acknowledgements}

The authors wish to thank Ms. Ritu Tuladhar, Ms. Sabita Thapa, Ms. Arati Shrestha, Ms. Manita Chaulagain and Ms. Moon Thapa for their help in field and laboratory works. The authors would like to thank Dr. Ramesh Prasad Sapkota for helping in data analysis.

\section{Authors' contributions}

SS conceptualized the study, conducted laboratory and field works. SS, BB, $\mathrm{NBD}$ and $\mathrm{HHY}$ contributed to the data analysis and manuscript writing. All authors read and approved the final manuscript.

\section{Funding}

No funding was received to carry out this study.

\section{Availability of data and materials}

All data generated or analyzed during this study are included in the article.

\section{Competing interests}

The authors declare they have no competing interests.

\section{Author details}

${ }^{1}$ Central Department of Environmental Science, Tribhuvan University, Kirtipur 44613, Nepal. ${ }^{2}$ Nepal Environmental Research Institute, Kathmandu 44600 , Nepal. ${ }^{3}$ Nature Conservation Initiative Nepal, Kathmandu 44600, Nepal. ${ }^{4}$ Department of Applied Chemistry, Chaoyang University of Technology, Taichung 413310, Taiwan. ${ }^{5}$ Department of Environmental Engineering and Management, Chaoyang University of Technology, Taichung 413310, Taiwan. ${ }^{6}$ Department of Environmental Science, Patan Multiple Campus, Tribhuvan University, Lalitpur 44700, Nepal.

\section{Received: 28 May 2020 Accepted: 14 December 2020}

Published online: 07 January 2021

\section{References}

1. Gulia S, Nagendra SMS, Khare M, Khanna I. Urban air quality management-a review. Atmos Pollut Res 2015;6:286-304.

2. Bahatola SS. Global burden of diseases attributable to air pollution. J Public Health Afr 2018:9:162-6.

3. WHO. Global health risks: mortality and burden of disease attributable to selected major risks. Geneva: World Health Organization; 2009.

4. WHO. Ambient air pollution: a global assessment of exposure and burden of disease. Geneva: World Health Organization; 2016.

5. Colvile RN, Hutchinson EJ, Mindell JS, Warren RF. The transport sector as a source of air pollution. Atmos Environ 2001;35:1537-65

6. Wang HK, Fu LX, Zhou Y, Du X, Ge WH. Trends in vehicular emissions in China's mega cities from 1995 to 2005. Environ Pollut 2010;158:394-400.

7. Wendling ZA, Emerson JW, de Sherbinin A, Esty DC. 2020 Environmenta Performance Index. New Haven: Yale Center for Environmental Law and Policy; 2020.

8. Pokhrel S. Green space suitability evaluation for urban resilience: an analysis of Kathmandu Metropolitan city, Nepal. Environ Res Commun 2019:1: 105003.

9. Janhall S. Review on urban vegetation and particle air pollution deposition and dispersion. Atmos Environ 2015;105:130-7.

10. Barwise $Y$, Kumar $P$. Designing vegetation barriers for urban air pollution abatement: a practical review for appropriate plant species selection. NPJ Clim Atmos Sci 2020;3:12.

11. Singh SN, Verma A. Phytoremediation of air pollutants: a review. In: Singh SN, Tripathi RD, editors. Environmental bioremediation technologies. Berlin, Heidelberg: Springer; 2007:293-314

12. Singh SK, Singh RK, Singh RS, Pal D, Singh KK, Singh PK. Screening potential plant species for arresting particulates in Jharia coalfield, India Sustain Environ Res 2019;29:37.
13. Pugh TAM, MacKenzie AR, Whyatt JD, Hewitt CN. Effectiveness of green infrastructure for improvement of air quality in urban street canyons. Environ Sci Technol 2012:46:7692-9.

14. Varshney CK, Mitra I. Importance of hedges in improving urban air quality. Landscape Urban Plan 1993;25:75-83.

15. Song YS, Maher BA, Li F, Wang XK, Sun X, Zhang HX. Particulate matter deposited on leaf of five evergreen species in Beijing, China: source identification and size distribution. Atmos Environ 2015;105:53-60.

16. Bowler DE, Buyung-Ali L, Knight TM, Pullin AS. Urban greening to cool towns and cities: a systematic review of the empirical evidence. Landscape Urban Plan 2010;97:147-55.

17. Curtis AJ, Helmig D, Baroch C, Daly R, Davis S. Biogenic volatile organic compound emissions from nine tree species used in an urban tree-planting program. Atmos Environ 2014;95:634-43.

18. Zupancic T, Westmacott C, Bulthuis M. The impact of green space on heat and air pollution in urban communities: a meta-narrative systematic review. Vancouver: David Suzuki Foundation; 2015.

19. Nadgorska-Socha A, Kandziora-Ciupa M, Trzesicki M, Barczyk G. Air pollution tolerance index and heavy metal bioaccumulation in selected plant species from urban biotopes. Chemosphere 2017;183:471-82.

20. Ivanov BN. Role of ascorbic acid in photosynthesis. Biochemistry Moscow 2014;79:282-9.

21. Heber U, Andrews TJ, Boardman NK. Effects of pH and oxygen on photosynthetic reactions of intact chloroplasts. Plant Physiol 1976;57:277-83.

22. Bharti SK, Trivedi A, Kumar N. Air pollution tolerance index of plants growing near an industrial site. Urban Clim 2018;24:820-9.

23. Molnar VE, Simon E, Tothmeresz B, Ninsawat S, Szabo S. Air pollution induced vegetation stress - the air pollution tolerance index as a quick tool for city health evaluation. Ecol Indic 2020;113:106234

24. Kanwar K, Dhamala MK, Maskey-Byanju R. Air pollution tolerance index: an approach towards the effective green belt around Kathmandu metropolitan city, Nepal. Nepal J Environ Sci 2016:4:23-9.

25. Adhikari GP. Road traffic accidents (RTAs) trends on Kathmandu-Bhaktapu road after addition of lanes. Open J Civ Eng 2016:6:388-96.

26. CBS. Environment Statistics of Nepal 2019. Kathmandu: Central Bureau of Statistics; 2019.

27. Glozer K. Protocol for leaf image analysis - surface area. Davis: University of California; 2008.

28. Barrs HD, Weatherley PE. A re-examination of the relative turgidity technique for estimating water deficits in leaves. Aus J of Biol Sci 1962;15: 413-28.

29. Arnon DI. Copper enzymes in isolated chloroplasts. Polyphenoloxidase in Beta vulgaris. Plant Physiol 1949;24:1-15.

30. Roy A, Bhattacharya T, Kumari M. Air pollution tolerance, metal accumulation and dust capturing capacity of common tropical trees in commercial and industrial sites. Sci Total Environ 2020;722:137622.

31. Bajaj KL, Kaur G. Spectrophotometric determination of L-ascorbic acid in vegetables and fruits. Analyst 1981;106:117-20.

32. Ogunkunle CO, Suleiman LB, Oyedeji S, Awotoye OO, Fatoba PO. Assessing the air pollution tolerance index and anticipated performance index of some tree species for biomonitoring environmental health. Agroforest Syst 2015:89:447-54

33. Zhang TJ, Yu LX, Zheng P, Li YJ, Rivera M, Main D, et al. Identification of loci associated with drought resistance traits in heterozygous autotetraploid alfalfa (Medicago sativa L.) using genome-wide association studies with genotyping by sequencing. PLOS One 2015;10:e0138931.

34. Tak AA, Kakde UB. Assessment of air pollution tolerance index of plants: a comparative study. Int J Pharm Pharm Sci 2017;9:83-9.

35. Tyree MT, Snyderman DA, Wilmot TR, Machado JL. Water relations and hydraulic architecture of a tropical tree (Schefflera morototoni): data, models, and a comparison with 2 temperate species (Acer Saccharum and Thuja Occidentalis). Plant Physiol 1991;96:1105-13.

36. Ksenzhek OS, Volkov AG. Plant energetics. 2nd ed. Amsterdam: Elsevier; 1998.

37. Lawlor DW. Limitation to photosynthesis in water-stressed leaves: stomata vs. metabolism and the role of ATP. Ann Bot 2002:89:871-85.

38. Singh SK, Rao DN, Agrawal M, Pandey J, Narayan D. Air-pollution tolerance index of plants. J Environ Manag 1991;32:45-55.

39. Li Y, He NP, Hou JH, Xu L, Liu CC, Zhang JH, et al. Factors influencing leaf chlorophyll content in natural forests at the biome scale. Front Ecol Evol 2018;6:64. 
40. Joshi PC, Swami A. Air pollution induced changes in the photosynthetic pigments of selected plant species. J Environ Biol 2009;30:295-8.

41. Pavlovic D, Nikolic B, Durovic S, Waisi H, Andelkovic A, Marisavljevic D. Chlorophyll as a measure of plant health: agroecological aspects. Pestic Phytomed 2014;29:21-34.

42. Woo SY, Je SM. Photosynthetic rates and antioxidant enzyme activity of Platanus occidentalis growing under two levels of air pollution along the streets of Seoul. J Plant Biol 2006;49:315-9.

43. Karmakar D, Deb K, Padhy PK. Ecophysiological responses of tree species due to air pollution for biomonitoring of environmental health in urban area. Urban Clim 2021;35:100741.

44. Rudolph E, Bukatsch F. The protochlorophyll (ide) transformation and its relation to the photooxidation of ascorbic acid in etiolated seedlings. Planta 1966;69:124-34.

45. Varshney SRK, Varshney CK. Effects of $\mathrm{SO}_{2}$ on ascorbic acid in crop plants. Environ Pollut A 1984;35:285-90.

46. Keller T, Schwager H. Air pollution and ascorbic acid. Eur J Forest Pathol 1977;7:338-50

47. Pandey AK, Pandey M, Mishra A, Tiwary SM, Tripathi BD. Air pollution tolerance index and anticipated performance index of some plant species for development of urban forest. Urban for Urban Gree 2015;14:866-71.

48. Zhang PQ, Liu YJ, Chen X, Yang Z, Zhu MH, Li YP. Pollution resistance assessment of existing landscape plants on Beijing streets based on air pollution tolerance index method. Ecotox Environ Safe 2016;132:212-23.

49. Rai PK, Panda LLS. Dust capturing potential and air pollution tolerance index (APTI) of some road side tree vegetation in Aizawl, Mizoram, India: an Indo-Burma hot spot region. Air Qual Atmos Health 2014;7:93-101.

50. Gawronski SW, Gawronska H, Lomnicki S, Sæbo A, Vangronsveld J. Plants in air phytoremediation. In: Cuypers A, Vangronsveld J, editors. Advances in botanical research. Amsterdam: Elsevier; 2017;83:319-46.

51. Li YM, Wang SJ, Chen QB. Potential of thirteen urban greening plants to capture particulate matter on leaf surfaces across three levels of ambient atmospheric pollution. Int J Env Res Pub Health 2019;16:402.

52. Kaur M, Nagpal A. Evaluation of air pollution tolerance index and anticipated performance index of plants and their application in development of green space along the urban areas. Environ Sci Pollut $R$ 2017;24:18881-95

\section{Publisher's Note}

Springer Nature remains neutral with regard to jurisdictional claims in published maps and institutional affiliations.

Ready to submit your research? Choose BMC and benefit from:

- fast, convenient online submission

- thorough peer review by experienced researchers in your field

- rapid publication on acceptance

- support for research data, including large and complex data types

- gold Open Access which fosters wider collaboration and increased citations

- maximum visibility for your research: over $100 \mathrm{M}$ website views per year

At $\mathrm{BMC}$, research is always in progress.

Learn more biomedcentral.com/submissions 